\title{
Education of Entrepreneurship and Activities of Entrepreneurship to Students' Interests
}

\author{
$1^{\text {st }}$ Novianti Rahmawati \\ Economic Education Department \\ STKIP Muhammadiyah Sampit \\ Sampit, Indonesia \\ novi@stkipmsampit.ac.id
}

\author{
$2^{\text {nd }}$ Mahmuddin \\ Economic Education Department \\ STKIP Muhammadiyah Sampit \\ Sampit, Indonesia \\ mahmudin@stkipmsampit.ac.id
}

\author{
$3^{\text {rd }}$ Siti Halimah \\ Economic Education Department \\ STKIP Muhammadiyah Sampit \\ Sampit, Indonesia \\ siti_halimah@stkipmsampit.ac.id
}

\begin{abstract}
This study aimed to determine the effect of entrepreneurship education and entrepreneurial activities on students' entrepreneurial interests partially or simultaneously. The population in this study were students of the Economic Education Study Program STKIP Muhammadiyah Sampit who programmed entrepreneurship courses in the academic year 2019/2020 was amount 42 people and the sampling technique used saturated samples. The collected data was using multiple linear regression analysis methods. This study used a questionnaire as a data collection tool. The results showed that there was an influence of the independent variables both partially and simultaneously on the dependent variable, namely entrepreneurship education, influencing student interest in entrepreneurship, entrepreneurial activity influencing student interest in entrepreneurship, and simultaneously entrepreneurship education and entrepreneurial activity influencing student interest in entrepreneurship with the magnitude of influence of the independent variables (entrepreneurship education and entrepreneurial activity) of $62.7 \%$ while the remaining $37.3 \%$ is influenced by other variables not examined. Therefore, suggestions given so that entrepreneurial interest can continue to increase include entrepreneurship education and entrepreneurial activities continue to be promoted not only included in the compulsory curriculum in lectures at STKIP Muhammadiyah Sampit will only be used by Entrepreneurship Students' Learning Unit, so that entrepreneurial knowledge and activities become more developed and there is an interest in becoming an entrepreneur.
\end{abstract}

Keywords- Entrepreneurship Education, Entrepreneurial Activities, Student Entrepreneurial Interest

\section{INTRODUCTION}

The problem of unemployment is one of the main problems in a country, as is the case in Indonesia. Especially with the era of the ASEAN Economic Community (AEC) which increasingly adds to the urgency of Indonesian people who are displaced by foreign workers who work in Indonesia. Unemployment generally occurs because job seekers are not proportional to the number of jobs that can absorb it. Data from the Central Statistics Agency (BPS) recently released Indonesian labor conditions as of February 2019 which showed that the unemployment rate fell to $5.01 \%$ or decreased by 50 thousand people over the past year. The open unemployment rate (TPT) amounts to 6.82 million. Although in aggregate the unemployment rate has decreased, but seen from the level of education diploma and college graduates are increasingly not working, for unemployment diploma graduates have increased from $6.4 \%$ to $6.9 \%$ while unemployment for college graduates has risen from $5.0 \%$ to $6.2 \%$ [1]. Today's college graduates are generally oriented towards becoming a worker such as being a civil servant or private employee. This shows that the education system in Indonesia gave birth to new job seekers rather than job creation, so the influence of universities in forming educated resources is expected to create young people who can open jobs for the wider community thereby reducing the number of unemployed. Therefore, one way to reduce unemployment is by entrepreneurship.

According to Hendro, entrepreneurship is an ability to manage something within oneself to be improved to be more optimal so that it can improve the standard of living in the future [2]. According to Saiman, entrepreneurship is an effort in creating business activities based on the will and desire of oneself. With entrepreneurship, it can create broad jobs, do not depend on others in getting jobs and can help the government in reducing unemployment by opening up jobs [3]. Saiman also added that entrepreneurs are people who have entrepreneurial qualities such as risk-taking, never giving up and having a strong will to succeed in managing their business based on their abilities and wills. Besides, an entrepreneur also has a greater income than being an employee. Entrepreneurship can also help increase domestic income through the tax sector. Before increasing the number of entrepreneurs and reducing unemployment in Indonesia, the community must be made aware of the importance of increasing entrepreneurial interest [3].

Entrepreneurial interest according to Sutanto in Rini Safitri is desire, interest, and willingness to work hard or have a strong will to try to fulfill their daily needs and create new businesses without fearing the risks that will occur and always learning from failures in entrepreneurship [4]. Meanwhile, according to Basrowi, interest in entrepreneurship is a change in the attitudes and views of the young generation of our nation's intellectual candidates and a change in the attitude of parents who like and allow their children to go into business [5]. In the research of Ahmad Tri Atmaja and Margunani, explaining, entrepreneurial interest is one's interest in creating a business by looking at opportunities that are around and dare to take risks that may occur in running a business. Someone interested in entrepreneurship will be seen in behaviors that lead to desires, it arises from within with courage to take risks and be responsive in handling 
opportunities that exist or are meant are people who want to work [6].

The results of pre-research conducted on students of the Economic Education Study Program STKIP Muhammadiyah Sampit Force 2017 at the beginning of the Odd Semester Academic Year 2019/2020 which programmed entrepreneurship courses, showed that of 42 students interested in entrepreneurship totalling 17 people and not interested in number 25 people. The following table show the results of pre-research observations about student entrepreneurial interest:

\begin{tabular}{|l|c|c|}
\hline \multicolumn{1}{|c|}{ Question } & Yes & No \\
\hline I am interested in entrepreneurship & 17 & 25 \\
\hline I come from an entrepreneurial family & 10 & 32 \\
\hline I have started and run a business & 8 & 34 \\
\hline I have taken an entrepreneurship course & 0 & 42 \\
\hline
\end{tabular}

Source: Pre-research observation results, 2019

Based on the above table, entrepreneurship interest in students of the STKIP Muhammadiyah Sampit Economic Education Study Program is still in the low category. This is because many factors influence it. According to Hendro, some factors influence entrepreneurial interest, including (1) individual / personal factors, (2) Education, (3) family encouragement, (4) compulsion and circumstances [2]. Meanwhile, according to Mc. Lelland in Ahmad Tri Atmaja and Margunani argued that entrepreneurship is determined by achievement motives, optimism, values, and entrepreneurial status or success [6]. The success of an entrepreneur is determined by entrepreneurial behavior. Entrepreneurial behavior is influenced by internal factors and external factors, internal factors are ownership rights, abilities/competencies, and incentives, while external factors include the environment, where factors originating from the environment include government policies, role models, opportunities, competitors, resources, besides it is also influenced by activity. Those from several existing theories, researchers want to know the variables that can affect entrepreneurial interest, and the variables chosen by researchers are entrepreneurial education and entrepreneurial activities.

Entrepreneurship education is usually included in the lecture curriculum that discusses the theoretical sciences of entrepreneurship. Entrepreneurship education is the science, art, and behavior, the nature, characteristics, and character of someone who can realize innovative ideas into the real world creatively [7]. Based on the description above, the need to give birth to new entrepreneurs encourages many universities to include entrepreneurship education in their curriculum.

In the Economic Education Study Program at STKIP Muhammadiyah Sampit has a variety of Community Life Courses (MBB), one of which is an entrepreneurship course. The purpose of this course is to equip students to become entrepreneurs who have ideas or business ideas that can read business opportunities, which in turn are encouraged to have a soul and interest in entrepreneurship. Besides being prepared to become educators, Economic Education Study Program students are also prepared to become entrepreneurs because their interest in entrepreneurship in Indonesia is still lacking, especially students of the Economic Education Study Program STKIP Muhammadiyah Sampit. Entrepreneurship course is one of the subjects of community life in the Economic Education Study Program that must be taken by students of the class of 2017 in Semester V (five) with a weight of 2 credits carried out in theory $40 \%$ and $60 \%$ practice. The practice that is carried out includes doing business by making a business plan proposal according to the ideas or business ideas of each student team and at the end of the practical activity reporting the results of the business activities that have been carried out. By taking the entrepreneurship course, it is expected that students can have an interest in becoming an entrepreneur and have an idea of opening their own business. Besides, entrepreneurship courses can provide insights into student career choices in the future, so students are expected to have alternative career choices, besides being civil servants or private employees. By owning their own business, they can have the freedom to apply creative ideas and also provide jobs for others.

\section{RESEARCH METHOD}

This type of research was quantitative research. The population in this study were students of the Economic Education Study Program STKIP Muhammadiyah Sampit who programmed entrepreneurship courses in 2019/2020 Academic Year totalling 42 people. The sampling technique used saturated samples. This study used a questionnaire as a data collection tool. The questionnaire used was a Likert scale to measure the variables of entrepreneurial interest (Y), entrepreneurship education (X1), and entrepreneurial activity (X2). The collected data was then analyzed using the multiple linear regression analysis method.

\section{RESULTS AND DISCUSSION}

The results of the descriptive statistical analysis on the variables of entrepreneurship education, entrepreneurial activity and interest in entrepreneurship are as follows Research Results:

TABLE I. THE RESULT OF DESCRIPTIVE STATISTICAL ANALYSIS OF VARIABLES

\begin{tabular}{|l|r|r|r|r|r|}
\hline & \multicolumn{1}{|c|}{$\mathrm{N}$} & \multicolumn{1}{c|}{ Min } & Max & Mean & $\begin{array}{c}\text { Std. } \\
\text { Deviation }\end{array}$ \\
\hline $\begin{array}{l}\text { Entrepreneurship } \\
\text { Education }\end{array}$ & 42 & 49 & 56 & 53,69 & 1,630 \\
\hline $\begin{array}{l}\text { Entrepreneurial } \\
\text { Activity }\end{array}$ & 42 & 53 & 63 & 61,45 & 1,915 \\
\hline Entrepreneurial Interest & 42 & 70 & 83 & 81,40 & 2,450 \\
\hline Valid N (listwise) & 42 & & & & \\
\hline
\end{tabular}

Based on the descriptive statistical test in the table above shows that the highest value of the variable entrepreneurship education of students is 56 of the 14 statement items, the lowest value is 49 and the average value of the variable entrepreneurship education is 53.69. While the highest value of the variable student entrepreneurial activity was 63 of the 16 statement items, the lowest value was 53 and the average value of the variable entrepreneurial activity was 61.45. Furthermore, the highest value of the variable student entrepreneurial interest is 83 of the 21 statement items, the lowest value is 70 and the average value of the variable entrepreneurial interest is 81.40. Before testing hypotheses using multiple linear regression, test assumptions or requirements must first be met in the regression model. This requirement or assumption goes through a series of classic assumption tests which include tests of normality, linearity, multicollinearity, and heteroscedasticity. 
Multiple linear regression analysis is a method or technique of analysis research hypotheses to test whether there is an influence of two or more independent variables (independent variables) on the dependent variable (the dependent variable). The regression equation can be seen in table II as follows:

TABLE II. RESULTS OF MULTIPLE LINEAR REGRESSION ANALYSIS

\begin{tabular}{|c|l|c|c|c|c|c|}
\hline & & \multicolumn{2}{|c|}{$\begin{array}{c}\text { Standar } \\
\text { dized } \\
\text { Coeffic } \\
\text { ients }\end{array}$} & t & Sig. \\
\hline & & B Coefficients & $\begin{array}{c}\text { Std. } \\
\text { Error }\end{array}$ & Beta & B & $\begin{array}{c}\text { Std. } \\
\text { Error }\end{array}$ \\
\hline 1 & (Constant) & 8,672 & 9,252 & &, 937 &, 354 \\
\hline & $\begin{array}{l}\text { Entrepreneur } \\
\text { ship } \\
\text { Education }\end{array}$ &, 332 &, 153 &, 221 & 2,167 &, 036 \\
\hline & $\begin{array}{l}\text { Entrepreneuri } \\
\text { al Activity }\end{array}$ &, 894 &, 130 &, 699 & 6,858 &, 000 \\
\hline
\end{tabular}

From the above data the regression model is obtained as follows:

$\mathrm{Y}=8,672+0,332 \mathrm{X} 1+0,894 \mathrm{X} 2$

The equation contains that meaning:

1. A constant of 8.672 means that if the entrepreneurship education variable (X1) and entrepreneurial activity (X2) have a value of 0 , then the interest in entrepreneurship of students of the STKIP Muhammadiyah Sampit (Y) Economic Education Study Program (Y) is 8.672.

2. If the entrepreneurial activity variable (X2) has a fixed value and the entrepreneurship education variable (X1) rises by one unit, then the entrepreneurial interest in entrepreneurship in the STKIP Muhammadiyah Sampit (Y) Economic Education Study Program will increase by 0.332 .

3. If the entrepreneurship education variable (X1) has a fixed value and the entrepreneurial activity variable (X2) increases by one unit, then the entrepreneurial interest in entrepreneurship in the STKIP Muhammadiyah Sampit (Y) Economic Education Study Program will increase by 0.894 .

Partial hypothesis testing (t-test) is used to determine whether each independent variable, namely entrepreneurship education and entrepreneurial activity, has a partial effect on student entrepreneurial interest through the assistance of the SPSS program. The basis for decision making in the t-test is by comparing $t_{\text {counts }}$ with $t_{\text {table. }}$. If the value of $t_{\text {count }}>t_{\text {table }}$, then there is the effect of the independent variable $(\mathrm{X})$ on the dependent variable (Y) or the hypothesis is accepted, meaning that the independent variable has a partial effect on the dependent variable. Following are the results of the partial research hypothesis test (t-test) which can be seen in table III below:

TABLE III. RESULTS OF T TEST

\begin{tabular}{|c|l|c|c|c|c|c|}
\hline & & \multicolumn{2}{|c|}{$\begin{array}{c}\text { Standar } \\
\text { dized } \\
\text { Unstandardize } \\
\text { Coeffic } \\
\text { ients }\end{array}$} & $\mathrm{t}$ & Sig. \\
\hline & & $\mathrm{B}$ & $\begin{array}{c}\text { Std. } \\
\text { Error }\end{array}$ & Beta & B & $\begin{array}{c}\text { Std. } \\
\text { Error }\end{array}$ \\
\hline 1 & (Constant) & 8,672 & 9,252 & &, 937 &, 354 \\
\hline
\end{tabular}

\begin{tabular}{|l|l|r|r|r|r|r|}
\hline & $\begin{array}{l}\text { Entrepreneur } \\
\text { ship } \\
\text { Education }\end{array}$ &, 332 &, 153 &, 221 & 2,167 &, 036 \\
\hline $\begin{array}{l}\text { Entrepreneuri } \\
\text { al Activity }\end{array}$ &, 894 &, 130 &, 699 & 6,858 &, 000 \\
\hline
\end{tabular}

Based on the table above shows that the $t_{\text {count }}$ value of entrepreneurship education variable (X1) is 2.167 because the $\mathrm{t}_{\text {count }}$ value is $2.167>\mathrm{t}_{\text {table }} 2.02269$, it can be concluded that there is an effect of entrepreneurship education on the entrepreneurial interest of students in the STKIP Muhammadiyah Sampit Economic Education Study Program the decision that $\mathrm{H} 1$ was accepted. In the entrepreneurial activity variable (X2) $t_{\text {count }}=6.858$, because $t_{\text {count }} 6.858>t_{\text {table }}$ 2.02269 , it can be concluded that there is an influence of entrepreneurial activity on the entrepreneurial interest of students of the STKIP Muhammadiyah Sampit Economic Education Study Program so that a decision is obtained that $\mathrm{H}_{2}$ is accepted.

Simultaneous hypothesis testing ( $F$ test) is intended to test the significance of joint or simultaneous influence of the independent variables on the dependent variable, namely entrepreneurship education and entrepreneurial activity on the entrepreneurial interest of students of the STKIP Muhammadiyah Sampit Economic Education Study Program, through the assistance of the SPSS program. The basis for decision making in the $\mathrm{F}$ test is by comparing the

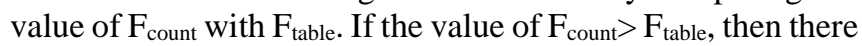
is the effect of the independent variable $(\mathrm{X})$ on the dependent variable (Y) or the hypothesis is accepted, meaning that the independent variable simultaneously influences the dependent variable. The following are the results of the simultaneous hypothesis test (F test) which can be seen in table IV below:

\begin{tabular}{|c|l|c|c|c|c|c|}
\multicolumn{7}{c|}{ TABLE IV. RESULTS OF F TEST } \\
\hline Model & & $\begin{array}{c}\text { Sum of } \\
\text { Squares }\end{array}$ & $\begin{array}{c}\text { Mean } \\
\text { Square }\end{array}$ & F & Sig. \\
\hline 1 & Regression & 158,741 & 2 & 79,370 & 35,426 &, $000(\mathrm{a})$ \\
\hline & Residual & 87,378 & 39 & 2,240 & & \\
\hline & Total & 246,119 & 41 & & & \\
\hline
\end{tabular}

Based on the table above shows that the value of $\mathrm{F}_{\text {count }}$ is 35.426 because the value of $F_{\text {count }}$ is $35.426>F_{\text {table }} 3.23$, it can be concluded that there is an influence of entrepreneurship education and entrepreneurial activities on the entrepreneurial interest of students in the STKIP Muhammadiyah Sampit Economic Education Study Program, to obtain a decision that $\mathrm{H}_{3}$ is accepted.

The coefficient of determination $\left(\mathrm{R}^{2}\right)$ means as a contribution of influence given the independent variable or independent variable $(\mathrm{X})$ to the dependent variable or the dependent variable $(\mathrm{Y})$ or in other words, the value of the coefficient of determination is useful for predicting and seeing how much the contribution of influence is given variable $\mathrm{X}$ simultaneously (together) with the Y variable. The coefficient of determination between 0 to 1 . If the coefficient $\left(\mathrm{R}^{2}\right)$ is closer to 1 , the ability of the independent variable in explaining the dependent variable is getting stronger. While the coefficient of determination $\left(\mathrm{R}^{2}\right)$ is getting closer to the value of 0 , it shows that the weaker ability of the independent variable in explaining the dependent variable is weaker. The following results of the analysis of the coefficient of 
determination $\left(\mathrm{R}^{2}\right)$ with the help of the SPSS program as follows:

TABLE VI. DETERMINATION COEFFICIENT TEST RESULTS $\left(\mathrm{R}^{2}\right)$

\begin{tabular}{|c|c|c|c|c|}
\hline Model & $\mathrm{R}$ & R Square & $\begin{array}{c}\text { Adjusted R } \\
\text { Square }\end{array}$ & $\begin{array}{c}\text { Std. Error of the } \\
\text { Estimate }\end{array}$ \\
\hline &, $803(\mathrm{a})$ &, 645 &, 627 & 1,497 \\
\hline
\end{tabular}

Based on the table above shows that the value of the Adjusted R Square $\left(\mathrm{R}^{2}\right)$ coefficient is 0.627 , which means that the variables of entrepreneurship education and entrepreneurial activities simultaneously (together) affect the entrepreneurial interest of students in the STKIP Muhammadiyah Sampit Economic Education Study Program at $62.7 \%$, while the remaining $37.3 \%$ is influenced by other variables outside this regression equation or variables not examined.

The results showed that there was an influence of the independent variables both partially and simultaneously on the dependent variable, namely (1) there was an influence of entrepreneurship education on student entrepreneurial interest ( $\left.t_{\text {count }} 2.167>t_{\text {table }} 2.02269\right)$ ); (2) there is an effect of entrepreneurial activity on student entrepreneurial interest ( $\left.\mathrm{t}_{\text {count }} 6.858>\mathrm{t}_{\text {table }} 2.02269\right)$; and (3) there is an influence of entrepreneurship education and entrepreneurial activity on student entrepreneurial interest $\left(\mathrm{F}_{\text {count }} 35.426>\mathrm{F}_{\text {table }} 3.23\right)$ with a magnitude of influence of $62.7 \%$. These results are in line with the opinion of Hendro, who said that there are factors that influence interest in entrepreneurship, one of which is Education. The education referred to here is entrepreneurship education [2]. Besides, Ciputra in Harefa and Siadari said that the factor influencing entrepreneurial interest was entrepreneurial activity [8]. In entrepreneurship learning, the main thing is practice, which is indicated by the existence of entrepreneurial activity. An entrepreneur must have experience in the form of knowledge gained from education, besides that he must also get used to doing practical activities that are accompanied by concrete activities.

At the STKIP Muhammadiyah Sampit Economic Education Study Program Entrepreneurship courses are one of the subjects of community life that must be taken by students of the class of 2017 in Semester V (five) with a weight of 2 credits which is carried out in theory $40 \%$ and $60 \%$ practice. The practice that is carried out includes doing business by making a business plan proposal according to the ideas or business ideas of each student team and at the end of the practical activity reporting the results of the business activities that have been carried out. By taking the entrepreneurship course, it is expected that students can have an interest in becoming an entrepreneur and have the picture to open their own business and someday graduates of the STKIP Muhammadiyah Sampit will not become contributors to unemployment if they do not get jobs by their field of education and choose a career as an entrepreneur as an alternative.

\section{CONCLUSIONS}

Based on the results of research that has been done, it can be concluded that the partial effect is found on each independent variable on the dependent variable, namely entrepreneurship education, influencing student interest in entrepreneurship and entrepreneurial activity influencing student interest in entrepreneurship. The simultaneous influence was also found that entrepreneurship education and entrepreneurial activities simultaneously influenced the interest in entrepreneurship students of STKIP Muhammadiyah Sampit with the influence of independent variables (entrepreneurship education and entrepreneurial activity) at $62.7 \%$ while the remaining $37.3 \%$ was influenced by variables another outside of this regression equation or variables not examined. Therefore, suggestions given so that entrepreneurial interest can continue to increase include entrepreneurship education and entrepreneurial activities continue to be promoted not only included in the compulsory curriculum in lectures at STKIP Muhammadiyah Sampit will only be used by Entrepreneurship Students' Learning Unit, so that entrepreneurial knowledge and activities become more developed and there is an interest in becoming an entrepreneur.

\section{REFERENCES}

[1] "Data Word," 17 May 2019. [Online]. Available: "Data Word,"May 17 2019. [Online]. Available: [3] https://dataword.co.id infographic/2019/05/17/number-unemployment-graduates-collegesincreased \#. [Accessed December 12, 2019]. [Accessed 12 December 2019].

[2] Hendro, Fundamentals of Entrepreneurship, Jakarta: Erlangga, 2011.

[3] L. Saiman, Entrepreneurship, Theory, Practice, and Cases, Jakarta: Salemba Empat, 2009.

[4] A. S. S. S. Rini Safitri, "Repository Unja," Universitas Jambi, [Online]. Available: http://repository.unja.ac.id/1260/1/ARTIKELRRA1A112068.pdf . [Accessed 13 December 2019].

[5] Basrowi, "Entrepreneurship, For Higher Education," Bogor, Ghalia Indonesia, 2016.

[6] A. T. A. d. Margunani, "Journal Unnes," Universitas Negeri Semarang, [Online]. Available: https://journal.unnes.ac.id/sju/index.php/eeaj/article/view/13578/7442. [Accessed 10 December 2019].

[7] R. H. Kristanto, in Entrepreneurship Entrepreneurship Management and Practice Approach, Yogyakarta, Graha Ilmu, 2009.

[8] A. d. E. E. S. Harefa, "The Ciputra Way Best Practices Become a True Entrepreneur," Jakarta, Elex Media Komputindo, 2010. 